\title{
Regulation of Root Length and Lateral Root Number in Trifoliate Orange Applied by Peroxide Hydrogen and Arbuscular Mycorrhizal Fungi
}

\author{
Chun-Yan LIU, Yong-Ming HUANG, Ying-Ning ZOU*, Qiang-Sheng WU \\ Yangtze University, College of Horticulture and Gardening, No 88 Jingmi Raod, Jingzhou, Hubei 434025, China; \\ zouyingning@163.com (*corresponding author)
}

\begin{abstract}
Root system morphology (RSM) in plants plays a key role in acquiring nutrients from the soil and is also altered by abiotic or biotic factors including soil microorganisms and signal molecules. The present study was made to evaluate the effects of an arbuscular mycorrhizal fungus (AMF, Glomus versiforme) and exogenous peroxide hydrogen $\left(\mathrm{H}_{2} \mathrm{O}_{2}, 0,1\right.$ and $\left.100 \mu \mathrm{M}\right)$ on root length, lateral root number and activities of polyamine-metabolized enzymes in trifoliate orange (Poncirus trifoliata) seedlings. After 5 months of inoculation with AMF, root mycorrhizal colonization was significantly increased by application of $1 \mu \mathrm{M}$ $\mathrm{H}_{2} \mathrm{O}_{2}$, but markedly restrained by $100 \mu \mathrm{M} \mathrm{H}_{2} \mathrm{O}_{2}$. Inoculation with AMF significantly increased the taproot length and the number of second-and third-order lateral roots under 1 and $100 \mu \mathrm{M} \mathrm{H}_{2} \mathrm{O}_{2}$ application. The AMF infection significantly increased 0-1 cm classed root length and total root length, regardless of $\mathrm{H}_{2} \mathrm{O}_{2}$ concentration. In general, inoculation with AMF increased arginine decarboxylase (ADC) and ornithine decarboxylase (ODC) activity of roots under 0,1 and $100 \mu \mathrm{M} \mathrm{H}_{2} \mathrm{O}_{2}$, increased diamine oxidase (DAO) activity of roots under $0 \mu \mathrm{M} \mathrm{H}_{2} \mathrm{O}_{2}$ and decreased DAO activity of roots under 1 and 100 $\mu \mathrm{M} \mathrm{H}_{2} \mathrm{O}_{2}$. Root polyamine oxidase ( $\mathrm{PAO}$ ) activity was similar between AMF and non-AMF seedlings, irrespectively of $\mathrm{H}_{2} \mathrm{O}_{2}$ concentration. Results suggest that lower concentration of $\mathrm{H}_{2} \mathrm{O}_{2}(1 \mu \mathrm{M})$ might be regarded as a signal to stimulate mycorrhizal and lateral root development through increase of $\mathrm{ADC}$ and $\mathrm{ODC}$ and decrease of $\mathrm{DAO}$, while high concentration of $\mathrm{H}_{2} \mathrm{O}_{2}$ $(100 \mu \mathrm{M})$ as a toxic compound of reactive oxygen species restricted AMF colonization.
\end{abstract}

Keywords: arginine decarboxylase, Glomus versiforme, ornithine decarboxylase, root morphology

\section{Introduction}

Root is a vital plant organ which absorbs water and nutrients from the soil. Meanwhile, root system morphology (RSM), the configuration and structure of the root system, can determine the transport capacity of root in soil nutrient and water (de Dorlodot et al., 2007). In general, rhizospheric nutritional status and microorganisms would highly impact RSM (Osmont $e$ t al., 2007; Chapman et al., 2011; Sato and Miura, 2011).

Arbuscular mycorrhizal fungi (AMF), a kind of soil inhabitant microorganism, can form a mutual symbiont with the roots of $\sim 80 \%$ of land plants, thus enhancing the uptake of mineral nutrition and water from the soil to the host plant, as well as withstanding various adversities (Koide and Mosse, 2004). Studies showed that inoculation with AMF could alter the RSM traits and promote the formation of lateral roots of higher order for the host plant (Yao et al., 2009). The AMF-mediated RSM improvement may be related to increased plant hormone biosynthesis proposed by Kaldorf and Ludwig-Müllerb (2000) in maize colonized by Glomus intraradices. Wu et al. (2011) found that the RSM alteration by mycorrhization may be due to the AMF-induced alteration of carbohydrates and peroxidase. However, other studies also revealed that AMF colonization did not alter RSM traits. Atkinson et al. (2003) found that root branching of Trifolium repens was not significantly affected by inoculation with $G$. mosseae. Herdlera et al. (2008) reported that the total root length and the root diameter of rice plants were notably decreased by the $G$. intraradices inoculation.

Hydrogen peroxide $\left(\mathrm{H}_{2} \mathrm{O}_{2}\right)$ as one of reactive oxygen species (ROS) generally acts a key regulator in a broad range of physiological processes, such as senescence (Peng et al., 2005), stomatal movement, cell cycle and growth and development (Deng et al., 2012). The $\mathrm{H}_{2} \mathrm{O}_{2}$ excess accumulation in plants could be used as ROS to induce oxidative burst in cells, thereby triggering cell death. On the other hand, $\mathrm{H}_{2} \mathrm{O}_{2}$ is also regarded as an important signal compound concerning the interaction of plants with pathogenic microorganisms (Apel and Hirt, 2004; Laloi $e t$ al., 2004), as well as many other processes referring to root biology, such as gravitropism, root elongation growth and root hair development (Zolla et al., 2010; Jiang et al., 2012). However, the interaction between AMF and $\mathrm{H}_{2} \mathrm{O}_{2}$ on RSM traits of the host plant is poorly known.

Diamine putrescine (Put), triamine spermidine (Spd) and tetraamine spermine (Spm), three types of polyamine (PAs), are formed either by the direct decarboxylation of Lornithine through ornithine decarboxylase (ODC) or by 
decarboxylation from $\mathrm{L}$-arginine to agmatine by arginine decarboxylase (ADC). The decomposition of PAs takes place under the two enzymes, diamine oxidase (DAO) and polyamine oxidase (PAO) (Kaur-Sawhney et al., 2003). It is well documented that PAs play important roles in mycorrhizal formation, plant growth, organ development, fruit formation and leaf senescence (Kusano et al., 2008; Wu et al., 2012b). In root development, accumulation of PAs is involved in the formation of adventitious root (Couée et al., 2004). Exogenous PAs could significantly promote the spore germination and hyphal growth of $G$. mosseae and Gigaspora margarita, in vitro culture conditions (Zhang et al., 2003). Wu et al. (2012a) observed that AMFmediated RSM improvement was related only to ADC and ODC, without any PAs concentrations. It seems that PA synthetase and degraded enzymes, except PA levels, were associated with AMF-mediated RSM. In addition, PA degradation may also act as a pathway to generate $\mathrm{H}_{2} \mathrm{O}_{2}$, which is considered to be an active secondary messenger (Vandenabeele et al., 2003). However, so far, in plants, the potential relationship between RSM and PA-metabolized enzymes under $\mathrm{H}_{2} \mathrm{O}_{2}$ and mycorrhization conditions has not been examined in detail.

The aims of the present work were to (1) clarify the integrated effects of AMF and $\mathrm{H}_{2} \mathrm{O}_{2}$ on root length, lateral root number and PA-metabolized enzymes of citrus and to (2) evaluate the relationship between RSM and PAmetabolized enzymes.

\section{Materials and methods}

\section{Plant culture}

Seeds of trifoliate orange [Poncirus trifoliata (L.) Raf.] were surface-sterilized with $70 \%$ ethanol solution for $5 \mathrm{~min}$, washed with distilled water and then sown into a plastic pot (18 cm upper diameter $\times 13 \mathrm{~cm}$ below diameter $\times 17 \mathrm{~cm}$ height) including $2.5 \mathrm{~kg}$ autoclaved $\left(121^{\circ} \mathrm{C}, 0.11 \mathrm{Mpa}, 2 \mathrm{~h}\right)$ soil. The inoculums of Glomus versiforme $(40 \mathrm{~g})$ including spore and extraradical hyphae were placed below $5 \mathrm{~cm}$ of the soil surface at the time of sowing. The non-AMF pots were also supplied with $40 \mathrm{~g}$ sterilized inoculums as the control.

\section{Experimental design}

The experiment consisted in a completely randomized design with two factors: inoculation with or without an AMF (G. versiforme) and application of exogenous $\mathrm{H}_{2} \mathrm{O}_{2}$ with 0,1 and $100 \mu \mathrm{M}$. Each treatment had three replicates, reaching a total of 18 pots. Three months after mycorrhizal inoculation, different concentrations $(0,1$ and $100 \mu \mathrm{M})$ of $\mathrm{H}_{2} \mathrm{O}_{2}$ were weekly applied into the designed pots, nine times during the experiment.

\section{Measurement of plant growth and root colonization}

The $\mathrm{AM}$ and non-AM plants were harvested after 63 days of exogenous $\mathrm{H}_{2} \mathrm{O}_{2}$ treatments. Before harvest, plant height, stem diameter and leaf number were directly determined.

Root mycorrhizal colonization was measured by the method of Phillips and Hayman (1970) after clearing with
$10 \% \mathrm{KOH}$ and staining with $0.05 \%$ trypan blue.

Determinations of root system morphology and lateral root number

The root systems were carefully taken out from the plastic pots and the intact root systems were scanned immediately by the Epson Perfection V700 Photo Dual Lens System (Seiko Epson Corp, Japan). The images of root systems were analyzed by a WinRHIZO version from 2007 (Regent Instruments Incorporated, Canada) and the 0-1, 1$2,2-3,3-4$ and $>4 \mathrm{~cm}$ classed root lengths were automatically obtained. Taproot lengths were measured by a flexible rule and the number of lateral roots was artificially quantified.

\section{Determinations of $P$ A-metabolized enzyme activities}

Activities of PA synthetases (ADC and ODC) and PAdegrading enzymes (PAO and DAO) were determined according to the methods previously described by Wu et al. (2012a).

\section{Statistical analyses}

Data were subjected to the analysis of variance (ANOVA) with SAS v8.1, and the significant differences among treatments were used for comparison to the Duncan test at $\mathrm{P}<0.05$.

\section{Results and discussion}

\section{Mycorrbizal colonization}

After inoculation with $G$. versiforme, root colonization of the trifoliate orange seedlings ranged from 55.28 to $75.91 \%$ (Fig. 1). Compared to $0 \mu \mathrm{M} \mathrm{H}_{2} \mathrm{O}_{2}$ control, $1 \mu \mathrm{M}$ $\mathrm{H}_{2} \mathrm{O}_{2}$ significantly increased $\mathrm{AMF}$ colonization by $16.6 \%$, whereas $100 \mu \mathrm{M} \mathrm{H}_{2} \mathrm{O}_{2}$ level notably decreased mycorrhizal infection by $15.1 \%$. There is increasing evidence indicating that during the early establishment of a symbiotic relationship, many plant signals and fungal perception are involved in the process (Requena et al., 2007). It seems that the low concentration of $\mathrm{H}_{2} \mathrm{O}_{2}(1 \mu \mathrm{M})$ might be regarded as a signal molecule to stimulate mycorrhizal development, while high concentration of $\mathrm{H}_{2} \mathrm{O}_{2}(100 \mu \mathrm{M})$ as a toxic compound of ROS restricted AMF colonization.

\section{Growth performance}

The present study showed that exogenous $\mathrm{H}_{2} \mathrm{O}_{2}$ and AMF colonization did not significantly alter the stem diameter of the seedlings (Tab. 1). Leaf number per plant was significantly higher in AMF than in non-AMF seedlings under 0 and $100 \mu \mathrm{M} \mathrm{H}_{2} \mathrm{O}_{2}$, except treatments under $1 \mu \mathrm{M} \mathrm{H}_{2} \mathrm{O}_{2}$ (Tab. 1). Compared to non-AMF seedlings, AMF seedlings showed notably higher plant height under $0 \mu \mathrm{M} \mathrm{H}_{2} \mathrm{O}_{2}$ conditions, but lower under 100 $\mu \mathrm{M} \mathrm{H}_{2} \mathrm{O}_{2}$ conditions. In addition, compared to $0 \mu \mathrm{M}$ $\mathrm{H}_{2} \mathrm{O}_{2}, 1$ and $100 \mu \mathrm{M} \mathrm{H}_{2} \mathrm{O}_{2}$ generally increased plant height and leaf number, suggesting that the low or high concentration of $\mathrm{H}_{2} \mathrm{O}_{2}$ did not absolutely interfere with the 
96

plant growth performance. Previous studies had shown that AMF could facilitate the growth of the host plants, attributed to extraradical hyphal absorption of water and mineral nutrients (Sharif and Claassen, 2011). Although low concentrations of $\mathrm{H}_{2} \mathrm{O}_{2}$ promoted root $\mathrm{AMF}$ colonization, the $\mathrm{H}_{2} \mathrm{O}_{2}$-induced increase of root colonization, they did not show significant effects on plant height, stem diameter and leaf number (Tab. 1). There was a significantly interacted effect of AMF and $\mathrm{H}_{2} \mathrm{O}_{2}$ on leaf

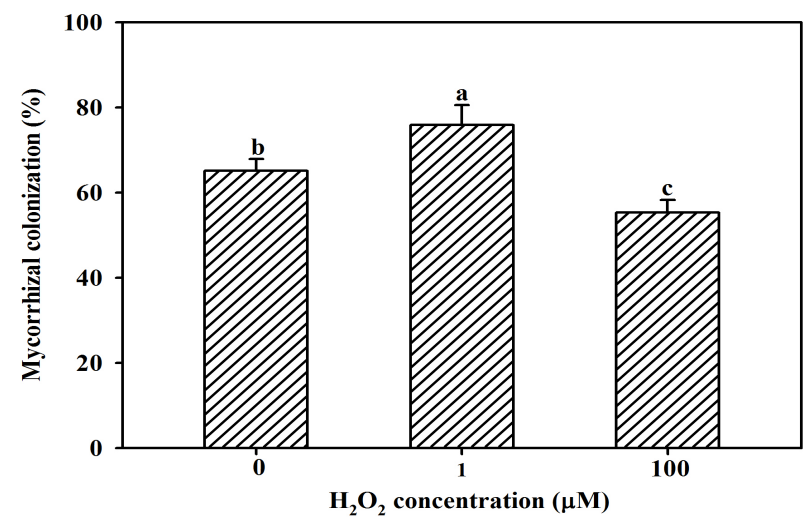

Fig. 1. Effect of exogenous $\mathrm{H}_{2} \mathrm{O}_{2}$ on AMF colonization of Glomus versiforme-inoculated trifoliate orange (Poncirus trifoliata) seedlings. Data (means \pm SE, $n=3$ ) followed by the different letter above the bars are significantly different at $P<0.05$.

Tab. 1. Effect of Glomus versiforme alone or in combination with exogenous $\mathrm{H}_{2} \mathrm{O}_{2}$ on growth performance of trifoliate orange (Poncirus trifoliata) seedlings

\begin{tabular}{ccccc}
\hline $\begin{array}{c}\mathrm{H}_{2} \mathrm{O}_{2} \\
\text { concentration } \\
(\mu \mathrm{M})\end{array}$ & Inoculation & $\begin{array}{c}\text { Plant height } \\
(\mathrm{cm})\end{array}$ & $\begin{array}{c}\text { Stem diameter } \\
(\mathrm{cm})\end{array}$ & $\begin{array}{c}\text { Leaf } \\
\text { number per } \\
\text { plant }\end{array}$ \\
\hline 0 & Non-AMF & $17.0 \pm 1.7 \mathrm{~d}$ & $0.227 \pm 0.005 \mathrm{a}$ & $15 \pm 0 \mathrm{c}$ \\
& AMF & $20.9 \pm 0.3 \mathrm{bc}$ & $0.237 \pm 0.018 \mathrm{a}$ & $18 \pm 1 \mathrm{~b}$ \\
\hline & Non-AMF & $20.3 \pm 0.6 \mathrm{c}$ & $0.237 \pm 0.011 \mathrm{a}$ & $19 \pm 0 \mathrm{ab}$ \\
& AMF & $21.5 \pm 1.1 \mathrm{bc}$ & $0.236 \pm 0.016 \mathrm{a}$ & $18 \pm 0 \mathrm{~b}$ \\
100 & Non-AMF & $24.2 \pm 0.8 \mathrm{a}$ & $0.249 \pm 0.027 \mathrm{a}$ & $18 \pm 0 \mathrm{~b}$ \\
& AMF & $22.3 \pm 1.1 \mathrm{~b}$ & $0.250 \pm 0.013 \mathrm{a}$ & $20 \pm 2 \mathrm{a}$ \\
\hline
\end{tabular}

Note: The data (means \pm SE, $n=3$ ) in a column followed by different letters are significantly different at $5 \%$ level.

number.

\section{Number of lateral roots}

Our results showed that the root systems of the five months old trifoliate orange seedlings were primarily dominated by first-order and second-order lateral roots (Tab. 2). Mycorrhizal inoculation significantly increased taproot length compared to non-mycorrhizal seedlings, irrespectively of exogenous $\mathrm{H}_{2} \mathrm{O}_{2}$ levels.

A study showed that inoculation with Paraglomus occultum significantly increased number of the lateral roots in Citrus tangerina plants (Wu et al., 2012b). The present study indicated that the AMF and exogenous $\mathrm{H}_{2} \mathrm{O}_{2}$ significantly influenced the number of the second-order and third-order lateral roots, but did not alter the number of the first-order lateral roots. This result is in compliance with the previous reports by Zai et al. (2007), who found that there was no significant influence on the number of first-order lateral roots between $\mathrm{AM}$ and non-AM trifoliate orange seedlings, but the number of the second-order lateral roots were markedly increased by mycorrhization.

\section{Different classed root lengths}

In the present study, the trifoliate orange seedlings in total root lengths depended on $0-1 \mathrm{~cm}$ classed root lengths (Tab. 3). Compared to non-AMF control, G. versiforme significantly increased $0-1 \mathrm{~cm}$ classed root lengths by 12.6 , 10.6 and $7.3 \%$ and $3-4 \mathrm{~cm}$ classed root lengths by 100,200 and $83.3 \%$ under 0,1 and $100 \mu \mathrm{M} \mathrm{H}_{2} \mathrm{O}_{2}$, respectively. In addition, the AMF seedlings showed higher total root lengths than the non-AMF controls, regardless of exogenous $\mathrm{H}_{2} \mathrm{O}_{2}$ concentration. The results imply that AMF highly induced elongation of lateral roots, which is not dependent on exogenous $\mathrm{H}_{2} \mathrm{O}_{2}$ level. Yao et al. (2009) reported that the fine roots lengths in trifoliate orange seedlings colonized by Gigaspora margarita, G. mosseae, G. versiforme and G. caledonium were with 35.0, 35.1, 30.5 and $45.5 \%$ higher than in non-AMF seedlings. In addition, AMF and exogenous $\mathrm{H}_{2} \mathrm{O}_{2}$ generally did not alter 1-2, 2-3, and $>4 \mathrm{~cm}$ classed root lengths, suggesting that the AMF and exogenous $\mathrm{H}_{2} \mathrm{O}_{2}$ mainly regulated the fine roots lengths

Tab. 2. Effects of Glomus versiforme and exogenous $\mathrm{H}_{2} \mathrm{O}_{2}$ on taproot length and number of lateral roots in trifoliate orange (Poncirus trifoliata) seedlings

\begin{tabular}{|c|c|c|c|c|c|}
\hline \multirow{2}{*}{$\begin{array}{c}\mathrm{H}_{2} \mathrm{O}_{2} \\
\text { concentration } \\
(\mu \mathrm{M})\end{array}$} & \multirow{2}{*}{ Inoculation } & \multirow{2}{*}{$\begin{array}{l}\text { Taproot } \\
\text { length } \\
(\mathrm{cm})\end{array}$} & \multicolumn{3}{|c|}{ Number of lateral roots } \\
\hline & & & First-order & $\begin{array}{l}\text { Second- } \\
\text { order }\end{array}$ & $\begin{array}{l}\text { Third- } \\
\text { order }\end{array}$ \\
\hline \multirow[t]{2}{*}{0} & Non-AMF & $18.2 \pm 0.6 c$ & $40 \pm 2 a$ & $74 \pm 3 c$ & $3 \pm 0 \mathrm{~cd}$ \\
\hline & $\mathrm{AMF}$ & $26.5 \pm 1.5 \mathrm{a}$ & $39 \pm 6 a$ & $60 \pm 3 b c$ & $7 \pm 0 \mathrm{ab}$ \\
\hline \multirow[t]{2}{*}{1} & Non-AMF & $21.8 \pm 1.2 b$ & $38 \pm 11 \mathrm{a}$ & $81 \pm 2 b$ & $4 \pm 2 c$ \\
\hline & $\mathrm{AMF}$ & $26.2 \pm 0.9 \mathrm{a}$ & $43 \pm 9 a$ & $89 \pm 5 a$ & $5 \pm 1 b c$ \\
\hline \multirow[t]{2}{*}{100} & Non-AMF & $22.7 \pm 0.9 b$ & $44 \pm 1 \mathrm{a}$ & $66 \pm 3 d$ & $2 \pm 2 d$ \\
\hline & AMF & $26.3 \pm 1.5 \mathrm{a}$ & $44 \pm 1 \mathrm{a}$ & $78 \pm 3 b c$ & $8 \pm 1 a$ \\
\hline
\end{tabular}
significantly different at $5 \%$ level.

(e.g., 0-1 cm classed root lengths).

\section{Activities of $P A$ synthetases $A D C$ and $O D C$}

Studies demonstrated that PAs are an important regulatory factor involved in the process of mycorrhizal formation (Wu et al., 2012b) and that the formation of PAs derives either from L-ornithine by ODC or from Larginine by $\mathrm{ADC}$, being disintegrated by $\mathrm{PAO}$ or $\mathrm{DAO}$ (EI Meskaoui and Trembaly, 2009). In the present study, ADC activity of both leaves and roots was generally significantly higher under AMF than under non-AMF treatment under 0 and $100 \mu \mathrm{M} \mathrm{H}_{2} \mathrm{O}_{2}$ levels, while under $1 \mu \mathrm{M} \mathrm{H}_{2} \mathrm{O}_{2}$ concentration AMF seedlings recorded higher ADC activity of roots and lower ADC activity of leaves than nonAMF seedlings (Fig. 2a, 2b). ODC activity of leaves was similar between AM and non-AM seedlings under 1 and $100 \mu \mathrm{M}$ and was significantly higher in AM than in nonAM seedlings grown in $0 \mu \mathrm{M} \mathrm{H}_{2} \mathrm{O}_{2}$ level (Fig. 2c). The $G$. versiforme increased the ODC activity of roots by $135.9,3.8$ and $7.8 \%$ under 0,1 and $100 \mu \mathrm{M} \mathrm{H}_{2} \mathrm{O}_{2}$, respectively (Fig. 
Tab. 3. Effect of Glomus versiforme and exogenous $\mathrm{H}_{2} \mathrm{O}_{2}$ on the different classed root lengths of trifoliate orange (Poncirus trifoliata) seedlings

\begin{tabular}{cccccccc}
\hline \multirow{2}{*}{$\begin{array}{c}\mathrm{H}_{2} \mathrm{O}_{2} \text { concentration } \\
(\mu \mathrm{M})\end{array}$} & Inoculation & \multicolumn{5}{c}{ Lengths of different classed roots $(\mathrm{cm})$} \\
\cline { 3 - 7 } & & $0-1 \mathrm{~cm}$ & $1-2 \mathrm{~cm}$ & $2-3 \mathrm{~cm}$ & $3-4 \mathrm{~cm}$ & $>4 \mathrm{~cm}$ & Total \\
\hline 0 & Non-AMF & $183.5 \pm 4.4 \mathrm{~b}$ & $6.1 \pm 2.8 \mathrm{a}$ & $3.9 \pm 1.4 \mathrm{a}$ & $0.4 \pm 0.6 \mathrm{~b}$ & $0.0 \pm 0.0 \mathrm{a}$ & $193.4 \pm 3.6 \mathrm{c}$ \\
& AMF & $206.8 \pm 5.8 \mathrm{a}$ & $6.7 \pm 1.6 \mathrm{a}$ & $3.9 \pm 0.9 \mathrm{a}$ & $0.8 \pm 0.5 \mathrm{ab}$ & $0.1 \pm 0.1 \mathrm{a}$ & $218.6 \pm 6.3 \mathrm{a}$ \\
& Non-AMF & $188.6 \pm 0.9 \mathrm{~b}$ & $7.2 \pm 2.9 \mathrm{a}$ & $4.4 \pm 1.3 \mathrm{a}$ & $0.5 \pm 0.3 \mathrm{ab}$ & $0.1 \pm 0.2 \mathrm{a}$ & $200.8 \pm 1.7 \mathrm{bc}$ \\
& AMF & $208.6 \pm 8.7 \mathrm{a}$ & $5.9 \pm 1.3 \mathrm{a}$ & $4.4 \pm 0.7 \mathrm{a}$ & $1.5 \pm 0.7 \mathrm{a}$ & $0.2 \pm 0.2 \mathrm{a}$ & $220.8 \pm 10.4 \mathrm{a}$ \\
& Non-AMF & $193.6 \pm 4.2 \mathrm{~b}$ & $7.0 \pm 0.2 \mathrm{a}$ & $3.9 \pm 1.5 \mathrm{a}$ & $0.6 \pm 0.1 \mathrm{ab}$ & $0.1 \pm 0.1 \mathrm{a}$ & $205.5 \pm 5.3 \mathrm{~b}$ \\
& AMF & $207.7 \pm 7.4 \mathrm{a}$ & $6.4 \pm 2.4 \mathrm{a}$ & $4.1 \pm 1.4 \mathrm{a}$ & $1.1 \pm 0.7 \mathrm{ab}$ & $0.1 \pm 0.1 \mathrm{a}$ & $219.5 \pm 5.4 \mathrm{a}$ \\
\hline
\end{tabular}

Note: The data (means \pm SE, $n=3$ ) in a column followed by different letters are significantly different at $5 \%$ level.

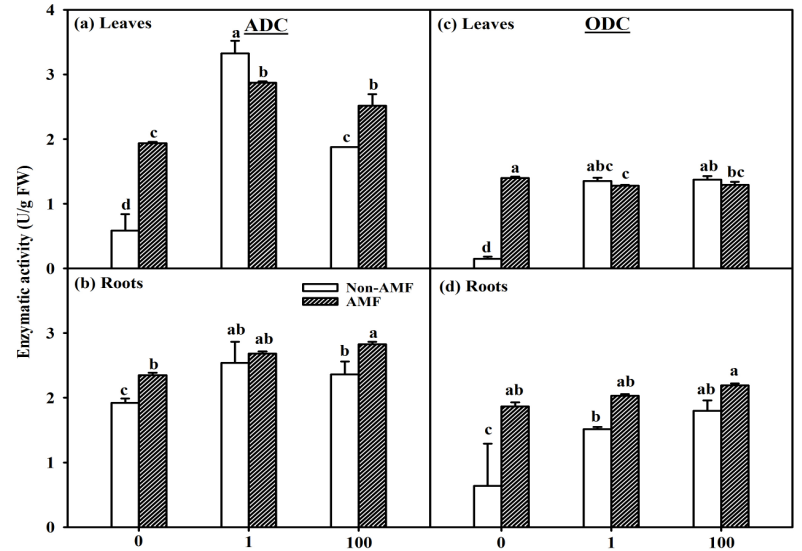

Fig. 2. Influence of Glomus versiforme and exogenous $\mathrm{H}_{2} \mathrm{O}_{2}$ on activity of PA synthetic enzymes (ADC and ODC) in leaves and roots of trifoliate orange (Poncirus trifoliata) seedlings. Data (means \pm SE, $n=3$ ) followed by the same letter above the bars are not significantly different at $P<0.05$

2d). It seems that AMF plants presented higher ADC and ODC activity of roots, irrespectively of exogenous $\mathrm{H}_{2} \mathrm{O}_{2}$ concentrations. It is well known that ADC is generally associated with cell expansion and ODC with cell division (Paschalidis and Roubelakis-Angelakis, 2005). Wu et al. (2012a) revealed that AMF-mediated RSM was related to the change of ADC and ODC activity. Therefore, in AMF seedlings, greater activity of ADC and ODC would benefit the development of lateral roots.

\section{Activities of $P A$-degrading enzyme $\mathrm{DAO}$ and $\mathrm{PAO}$}

As compared to that of the non-mycorrhizal seedlings, DAO and PAO activities in leaves of the mycorrhizal seedlings decreased by 31.0 and $19.4 \%$ (Fig. 3a, 3c) and $\mathrm{DAO}$ and $\mathrm{PAO}$ in roots by 19.6 and $7.0 \%$ under $100 \mu \mathrm{M}$ $\mathrm{H}_{2} \mathrm{O}_{2}$ treatment, respectively (Fig. $3 \mathrm{~b}, 3 \mathrm{~d}$ ). Under $1 \mu \mathrm{M}$ $\mathrm{H}_{2} \mathrm{O}_{2}$ treatment, DAO and PAO activities in leaves and roots were similar between AMF and non-AMF seedlings. Under $0 \mu \mathrm{M} \mathrm{H}_{2} \mathrm{O}_{2}$ concentration conditions, PAO activity in leaves and roots of AMF and non-AMF seedlings was not significantly different, but lower leaf DAO and higher root $\mathrm{DAO}$ were found in AMF seedlings. DAO and PAO are not only involved in the degradation of PAs, but also in the production of $\mathrm{H}_{2} \mathrm{O}_{2}$, during root cell growth and

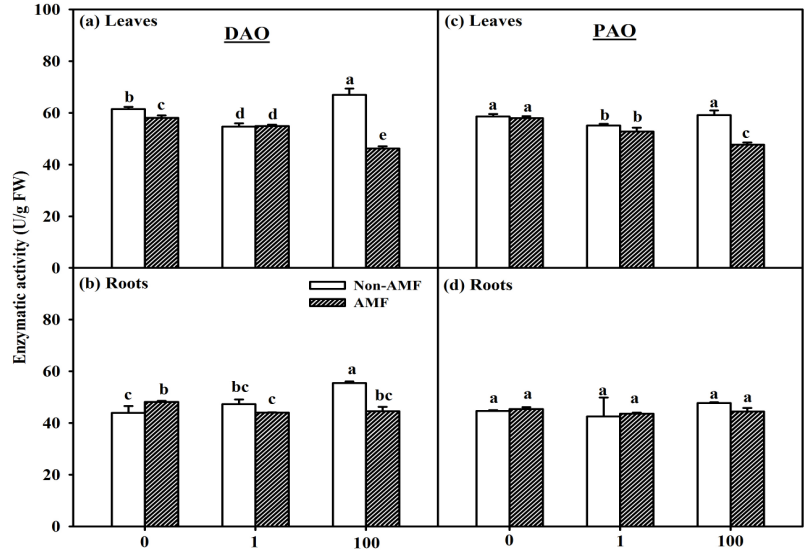

Fig. 3. Effects of Glomus versiforme and exogenous $\mathrm{H}_{2} \mathrm{O}_{2}$ on activity of PA-metabolic enzymes (DAO and PAO) in leaves and roots of trifoliate orange (Poncirus trifoliata) seedlings. Data (means \pm SE, $n=3$ ) followed by the same letter above the bars are not significantly different at $P<0.05$

differentiation (Wisniewski et al., 2000). Since no significant differences in PAO of roots were observed between AMF and non-AMF trifoliate orange seedlings under 1 and $100 \mu \mathrm{M} \mathrm{H}_{2} \mathrm{O}_{2}$ application, higher total root length and number of second-order and third-order lateral roots in AMF seedlings were not related to PAO.

\section{Conclusions}

Low concentration $(1 \mu \mathrm{M})$ of exogenous $\mathrm{H}_{2} \mathrm{O}_{2}$ may act as an important regulating factor of mycorrhizal development in trifoliate orange seedlings inoculated with Glomus versiforme, but high concentration $(100 \mu \mathrm{M})$ of exogenous $\mathrm{H}_{2} \mathrm{O}_{2}$ may confer oxidative damage and thus restrict root mycorrhizal colonization. In addition, under application of a low $\mathrm{H}_{2} \mathrm{O}_{2}$ concentration $(1 \mu \mathrm{M})$ conditions, AMF colonization significantly increased the number of second-order later root and total roots length (mainly 0-1 $\mathrm{cm}$ classed roots length), which were related to the increase of ADC and ODC and the decrease of DAO in roots.

\section{Acknowledgements}

This research was supported by the National Natural 
98

Science Foundation of China (31101513).

\section{References}

Apel K, Hirt H (2004). Reactive oxygen species: metabolism, oxidative stress and signal transduction. Ann Rev Plant Biol 55:373-399.

Atkinson D, Black KE, Forbes PJ, Hooker JE, Baddeley JA, Watson CA (2003). The influence of arbuscular mycorrhizal colonisation and environment on root development in soil. Eur J Soil Sci 54:751-757.

Chapman N, Whalley WR, Lindsey K, Miller AJ (2011). Water supply and not nitrate concentration determines primary root growth in Arabidopsis. Plant Cell Environ 34:1630-1638.

Couée I, Hummel I, Sulmon C, Gouesbet G, Amrani AE (2004). Involvement of polyamines in root development. Plant Cell Tiss Org Cult 76:1-10.

de Dorlodot S, Forster B, Pages L, Price A, Tuberosa R, Draye $X$ (2007). Root system architecture: opportunities and constraints for genetic improvement of crops. Trend Plant Sci 12:474-481.

Deng XP, Cheng YJ, Wu XB, Kwak SS, Chen W, Eneji AE (2012). Exogenous hydrogen peroxide positively influences root growth and metabolism in leaves of sweet potato seedlings. Aust J Crop Sci 6:1572-1578.

El Meskaoui A, Trembaly FM (2009). Effects of exogenous polyamines and inhibitors of polyamine biosynthesis on endogenous free polyamine contents and the maturation of white spruce somatic embryos. Afr J Biotech 8:6807-6816.

Herdlera S, Kreuzera K, Scheua S, Bonkowski M (2008). Interactions between arbuscular mycorrhizal fungi (Glomus intraradices, Glomeromycota) and amoebae (Acanthamoeba castellanii, Protozoa) in the rhizosphere of rice (Oryza sativa). Soil Biol Biochem 40:660-668.

Jiang J, Su M, Wang L, Jiao C, Sun Z, Cheng W, Li F, Wang C (2012). Exogenous hydrogen peroxide reversibly inhibits root gravitropism and induces horizontal curvature of primary root during grass pea germination. Plant Physiol Biochem 53:8493.

Kaldorf M, Ludwig-Müllerb J (2000). AM fungi might affect the root morphology of maize by increasing indole-3-butyric acid biosynthesis. Physiol Plant 109:58-67.

Kaur-Sawhney R, Tiburcio AF, Altabella T, Galston AW (2003). Polyamines in plants: An overview. J Cell Mol Biol 2:1-12.

Koide RT, Mosse B (2004). A history of research on arbuscular mycorrhiza. Mycorrhiza 14:145-163.

Kusano T, Berberich T, Tateda C, Takahashi Y (2008). Polyamines: essential factors for growth and survival. Planta 228:367-381.

Laloi C, Apel K, Danon A (2004). Reactive oxygen signalling: the latest news. Curr Opin Plant Biol 7:323-328.

Osmont KS, Sibout R, Hardtke CS (2007). Hidden branches: developments in root system architecture. Ann Rev Plant Biol 58:93-113.

Peng LT, Jiang YM, Yang SZ, Pan SY (2005). Accelerated senescence of fresh-cut Chinese water chestnut tissues in relation to hydrogen peroxide accumulation.J Plant Physiol Mol Biol 31:527-532.

Phillips JM, Hayman DS (1970). Improved procedures for clearing roots and staining parasitic and vesicular-arbuscular mycorrhizal fungi for rapid assessment of infection. Trans Br Mycol Soc 55:158-161.

Requena N, Serrano E, Ocon A, Breuninger M (2007). Plant signals and fungal perception during arbuscular mycorrhiza establishment. Phytochem 68:33-40.

Sato A, Miura K (2011). Root architecture remodeling induced by phosphate starvation. Plant Signal Behav 6:1122-1126.

Sharif M, Claassen N (2011). Action mechanisms of arbuscular mycorrhizal fungi in phosphorus uptake by Capsicum annuum $\mathrm{L}$. Pedosphere 21:502-511.

Vandenabeele S, Van Der Kelen K, Dat J, Gadjev I, Boonefaes T, Morsa S, Rottiers P, Slooten L, Van Montagu M, Zabeau M (2003). A comprehensive analysis of hydrogen peroxide-induced gene expression in tobacco. Proc Natl Acad Sci 100:16113-16118.

Wisniewski JP, Rathbun EA, Knox JP, Brewin NJ (2000). Involvement of diamine oxidase and peroxidase in insolubilization of the extracellular matrix: implications for pea nodule initiation by Rhizobium leguminosarum. Mol Plant Microbe Interact 13:413-420.

Wu QS, He XH, Zou YN, Liu CY, Xiao J, Li Y (2012a). Arbuscular mycorrhizas alter root system architecture of Citrus tangerine through regulating metabolism of endogenous polyamines. Plant Growth Regul 68:27-35.

Wu QS, Zou YN, He XH, Luo P (2011). Arbuscular mycorrhizal fungi can alter some root characters and physiological status in trifoliate orange (Poncirus trifoliata L. Raf.) seedlings. Plant Growth Regul 65:273-278.

Wu QS, Zou YN, Liu CY, Lu T (2012b). Interacted effect of arbuscular mycorrhizal fungi and polyamines on root system architecture of citrus seedlings.J Integr Agric 11:1675-1681.

Yao Q, Wang LR, Zhu HH, Chen JZ (2009). Effect of arbuscular mycorrhizal fungal inoculation on root system architecture of trifoliate orange (Poncirus trifoliata L. Raf.) seedlings. Sci Hortic 121:458-461.

Zhang Y, Xie LY, Xiong BQ, Zeng M (2003). Effect of polyamine on growth and development of arbuscular mycorrhizal fungi in vitro culture condition. Mycosyst 22:417-423.

Zai XM, Qin P, Wan SW, Zhao FG, Wang G, Yan DL, Zhou J (2007). Effects of arbuscular mycorrhizal fungi on the rooting and growth of beach plum (Prunus maritima) cuttings. J Hortic Sci Biotechnol 82:863-866.

Zolla G, Heimer YM, Barak S (2010). Mild salinity stimulates a stress-induced morphogenic response in Arabidopsis thaliana roots. J Exp Bot 61:211-224. 